\title{
Adjustments in the tetrazolium test methodology for assessing the physiological quality of Jatropha mollissima (Euphorbiaceae)
}

\author{
Adecuación metodológica de la prueba de tetrazolio para semillas \\ de Jatropha mollissima (Euphorbiaceae)
}

\author{
Letícia Siqueira Walter a,b*, Mônica Moreno Gabira ${ }^{\text {b, }}$ \\ Marcelle Almeida da Silva ${ }^{c}$, Antonio C Nogueira ${ }^{b}$, Dagma Kratz ${ }^{\text {b }}$ \\ ${ }^{a}$ CIFLOMA, Av. Pref. Lothário Meissner, s/n, Jd, Botânico, Curitiba-PR, Brasil, tel.: +55 (81) 999758179. \\ *Autor de correspondência: ${ }^{\text {* }}$ Universidade Federal do Paraná, Departamento de Ciências Florestais, \\ Laboratório de Sementes Florestais, Curitiba, Brasil, leticiasiqueira.walter@gmail.com \\ c Universidade Federal do Vale do São Francisco, Departamento de Biologia, Laboratório de Fisiologia Vegetal,
} Petrolina, Brasil.

\section{SUMMARY}

\begin{abstract}
Jatropha mollissima is a species of the semiarid region of northeastern Brazil. It is known that individuals of the same species may present differences in seeds viability, thus it is necessary to define methodologies to evaluate the physiological potential of seeds. This study aimed at determining the best pre-moistening time and the concentration of the tetrazolium solution to evaluate the viability of J. mollissima seeds. Three pre-moistening times were tested $(12,14$ and 16 hours) and two tetrazolium solution concentrations $(0.25$ and $0.5 \%$ ). As a comparative study, a germination test was performed, which consisted of two treatments: seeds between paper and on vermiculite. The values obtained in the tetrazolium test were similar, with average viable seeds of $21.3 \%$ for concentration $0.25 \%$ and $27.3 \%$ for the concentration of $0.5 \%$. It was observed, in the germination test, that the percentage of germination had averages equal to $22.5 \%$ for the treatment between paper and $13.5 \%$ for the treatment with vermiculite. The best procedure for performing the tetrazolium test in J. mollissima seeds is using the concentration of $0.25 \%$ of tetrazolium solution, pre-moistening time of 16 hours, between paper at $25^{\circ} \mathrm{C}$ and staining for 4 hours at $40{ }^{\circ} \mathrm{C}$ in the dark.
\end{abstract}

Key words: caatinga, pinhão-bravo, seeds analysis, viability.

\section{RESUMEN}

Jatropha mollissima es una especie que se encuentra en Caatinga, región semiárida del Nordeste Brasileño. Se sabe que los individuos de la misma especie pueden presentar diferencias en la viabilidad, por lo que es necesario definir metodologías para evaluar el potencial fisiológico de las semillas, especialmente para ajustar estándar de calidad. El objetivo de esta investigación fue determinar el mejor tiempo de humectación previa y la concentración de la solución de tetrazólio más adecuada para evaluar la viabilidad de las semillas de J. mollissima. Se probaron tres tiempos de humectación previa: 12,14 y 16 h y dos concentraciones de solución de tetrazolio $(0,25$ y $0,5 \%$ ). A modo de comparación, se realizó una prueba de germinación con dos tratamientos: entre papel y vermiculita. Los valores obtenidos en los tres tiempos y en las dos concentraciones fueran similares, con semillas viables con un promedio de $21,3 \%$ para 0,25 $\%$ y $27,3 \%$ para $0,5 \%$. Se observó en la prueba de germinación que el porcentaje de germinación tenía promedios iguales a $22,5 \%$ para el tratamiento con papel y 13,5\% para el tratamiento con vermiculita. Se sugiere que el mejor procedimiento para realizar la prueba de tetrazolio en las semillas de Jatropha mollissima es usar una concentración de $0,25 \%$ de sal de tetrazolio, 16 horas de tiempo de humectación previa, entre papel a $25^{\circ} \mathrm{C}$ y coloración por 4 horas a $40{ }^{\circ} \mathrm{C}$ en la obscuridad.

Palabras clave: Caatinga, pinhão-bravo, análisis de semillas, viabilidad.

\section{INTRODUCTION}

Jatropha mollissima (Pohl) Baill. (syn. Jatropha pohliana var. mollissima (Pohl) Müll (Euphorbiaceae), known as pinhão-bravo, is an endemic species of the Caa- tinga (Lima 2012, Maia 2012, IBGE 2012). It is a small tree, with arbustive character and ramifications (Vasconcelos et al. 2014). According to several investigations, the species of the genus Jatropha have medicinal properties contained in the latex and in the seeds oil (Maia 2012, Vas- 
concelos et al. 2014, Gomes 2015, Paterlini et al. 2019, Souza and Cavalcanti 2019) besides being sources for the production of biodiesel (Loureiro et al. 2013, Queiroz et al. 2013). Given its importance, studies are indispensable for the development of technologies related to the cultivation of the species. Such as the viability of seeds produced and collected for seedling production.

Analysis of the viability of seed lots through biochemical assessments such as tetrazolium are effective to characterize the physiological quality of seeds, given its speed and precision (MAPA 2009, Dantas et al. 2015, Marcos Filho 2015). With this test, we can also evaluate the possible causes for the reduction of the germinative potential of the seeds (Pinto et al. 2009, Marcos Filho 2015). Because it is a visual assessment, the determination of viable and unviable seeds may become subjective, since the seeds are evaluated according to their coloration (Ferreira and Borghetti 2004). For this reason, it is important to have well-defined protocols for this type of evaluation.

The principle of the tetrazolium test consists of evaluating the viability through reduction reactions occurring between the living tissues of the seeds when immersed in the tetrazolium solution, forming a red-colored compound known as triphenylformazan (Santos et al. 2006, MAPA 2009, Deminincis 2014). This reaction is generated by respiratory activity in the mitochondria, indicating the viability of the seeds according to the intensity of the color (Barros and Marcos Filho 1990, Oliveira et al. 2014, França Neto and Krzyzanowski 2019), associated with the stage of embryo development (Mercado and Delgado 2018, França Neto and Krzyzanowski 2019).

Several factors may interfere with this assessment, such as age, stage of deterioration, concentration of tetrazolium solution and also the time of exposure of the seed to the solution (Añez et al. 2005, Oliveira et al. 2014, Mercado and Delgado 2018). To better define the protocol of the tetrazolium test, results must be compared with the germination pattern, to ensure that results are reliable and compatible with the reality of the species.

In recent years, studies concerning J. mollissima have been related to the morphological description or reproductive biology, for example (Neves et al. 2010, Neves et al. 2011, Queiroz et al. 2013, Vasconcelos et al. 2014, Souza and Cavalcante 2019). For viability analyses, there are still no methodologies established for the species, and it is necessary to adapt protocols of other species to perform the analyses (Pinto et al. 2009). It is more common to observe well-established tetrazolium test protocols for agricultural species (França Neto and Krzyzanowski 2019) such as Glycine max (soy) (França Neto and Krzyzanowski 1998, Santos et al. 2006, Mercado and Delgado 2018).

Given the above, the objective of this study is to determine the best pre-moistening time and the concentration of the tetrazolium solution to evaluate the viability of Jatropha mollissima seeds.

\section{METHODS}

The seeds of J. mollissima were collected by the Seed Network of the São Francisco Integration Project, the Ecology and Environmental Monitoring Center (NEMA/UNIVASF). The fruits were collected in the city of Floresta/ $\mathrm{PE}$, under the coordinates $08^{\circ} 36^{\prime} 04^{\prime \prime} \mathrm{S}$ and $38^{\circ} 34^{\prime} 07^{\prime \prime} \mathrm{W}$ at $316 \mathrm{~m}$ altitude, from 12 mother trees and sent to the Laboratory of Forest Seeds of the Federal University of Paraná, in Curitiba, Paraná, where the research was conducted.

Previously, some research was performed to define the best time and the pre-moistening method. Based on the results, we used as treatments for pre-moistening the times in which the seeds had $30-40 \%$ of moisture, according to Pinto et al. (2009). For this purpose, three pre-moistening times were tested: 12,14 and 16 hours, between paper, which were maintained in a B.O.D. germinating at $25^{\circ} \mathrm{C}$, allowing slow soaking to stimulate the germination process and prepare the seeds (Ferreira and Borghetti 2004). Two concentrations of tetrazolium solution $(0.25$ and $0.5 \%)$ were also used, in four replications of 25 seeds. The solution of tetrazolium was prepared as the methodology describe at RAS (MAPA 2009), using the pattern solutions.

Subsequently, the seed caruncle and tegument were removed, keeping the integrity of endosperm and embryo (figure 1) which were submerged in tetrazolium solutions. The seeds in solution were kept in packaging covered by aluminum foil, since salt is photosensitive, and packed for $4 \mathrm{~h}$ at $40^{\circ} \mathrm{C}$ in B.O.D.

After the staining period, the seeds were washed with distilled water to remove the excess of tetrazolium solution and packaged in containers with distilled water. For the evaluation, the seeds were cut in the longitudinal direction and evaluated in a stereomicroscope and visually classified in viable and unviable seed.

The best pre-moistening time was determined according to the uniformity of tissue staining and the germination test. The germination consisted of eight replications of 25 seeds packed in gerbox-type boxes with different substrates: between paper (BP) and fine vermiculite (FV). In the BP treatment, two sheets of blotting paper were saturated with water and, for the FV treatment, $90 \mathrm{~mL}$ of distilled water was added to $30 \mathrm{~g}$ of fine vermiculite. In both treatments, water was replaced as needed.

The gerbox-type boxes were kept in B.O.D. germinating at $25^{\circ} \mathrm{C}$ and the germination was counted daily until it was stabilized, which occurred 13 days after installation. Seeds presenting radicle emission $\geq 2 \mathrm{~mm}$ were considered germinated. From these data, we calculated the percentage of germination $(\% \mathrm{G})$ and the mean germination time (MGT), according to Labouriou (1983) and germination speed index (GSI), according to Maguire (1962).

Data were subjected to the Bartlett homogeneity test and Shapiro-Wilk normality test. After that, data were submitted to ANOVA and Tukey test $(P<0.05)$, using the software Minitab 18. 


\section{RESULTS}

Seeds were considered viable by tetrazolium test when presented embryo with pink coloration, without indication of dark red/wine, and with most of the colored endosperm (figures 2A, 2B). Unviable seeds presented embryo or part of the embryonic axis with dark red/purple color (figures 2D, E), because this is indicative that this region is presenting excessive respiratory activity, close to becoming immutable or deteriorated; embryo with white coloration (figure 2C); endosperm with white coloration in more than $50 \%$ (figure 2D) and seeds presented deformities in the embryo (figures $2 \mathrm{~F}, 2 \mathrm{H}$ ) or endosperm with yellowish or necrosed staining (figure $2 \mathrm{G}$ ).
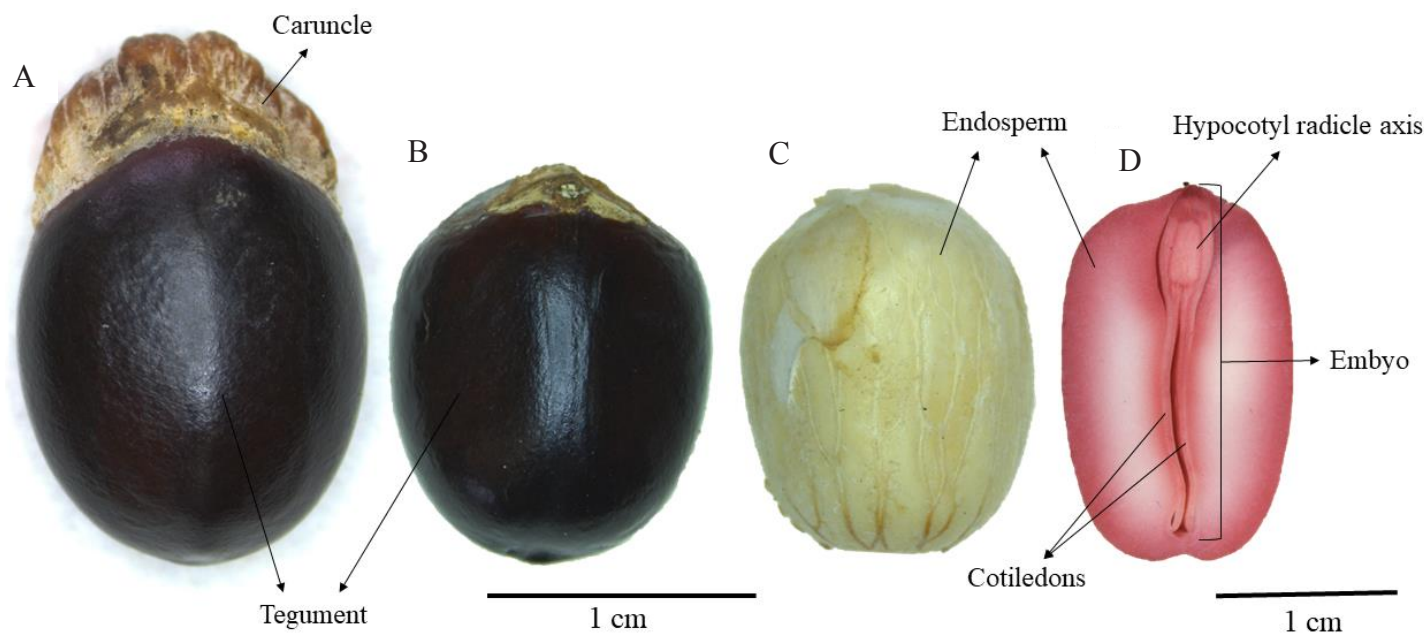

Figure 1. Jatropha mollissima seeds (A) with tegument and caruncle, (B) without caruncle and (C) without tegument and (D) longitudinal cut to evaluation. Source: Author (2018).

Preparación de semillas de Jatropha mollissima. (A) Con tegumento y carúncula, (B) sin carúncula, y (C) sin tegumento y (D) corte longitudinal para evaluación. Fuente: Autor (2018).

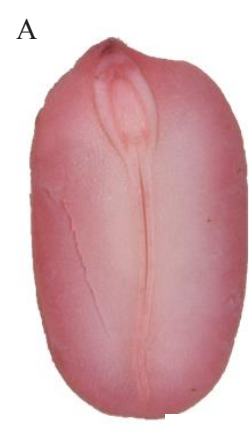

B

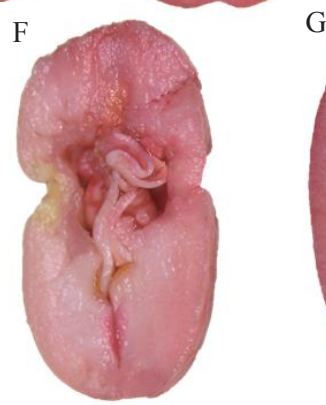

C

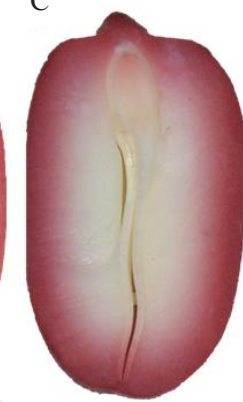

G

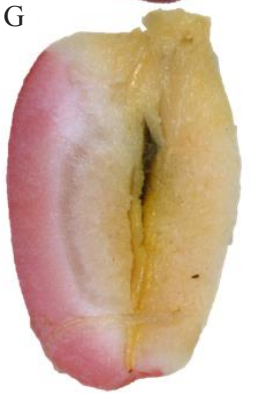

$\mathrm{D}$

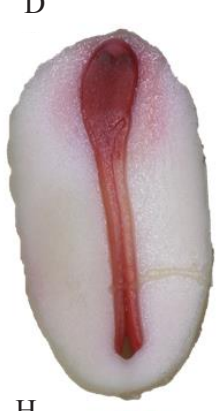

$\mathrm{H}$

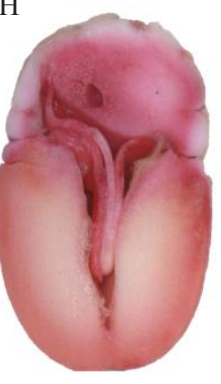

E

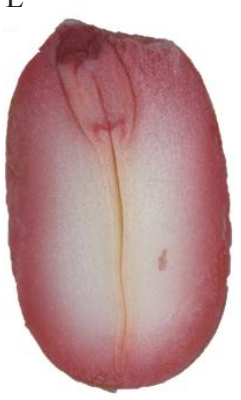

$1 \mathrm{~cm}$

Figure 2. Classification of Jatropha mollissima seeds by tetrazolium test: (A, B) viable and (C, D, E, F, G, H) unviable form. Source: Author (2018).

Clasificación de semillas viables (A, B) and no viables (C, D, E, F, G, H) de Jatropha mollissima por la prueba de tetrazólio. Fuente: Autor (2018). 
The values obtained in the three schedules and the two concentrations for the tetrazolium test were similar, with average viable seeds equal to $21.3 \%$ and $27.3 \%$; unviable equal $68.3 \%$ and $64.6 \%$; and deteriorated from $9.6 \%$ and $80 \%$ for concentrations of $0.25 \%$ and $0.5 \%$, respectively (table 1). As predicted, the most concentrated solution was more responsive to the evaluation. However, considering the similarity, it is recommended to use the concentration of $0.25 \%$, given the reduced use of reagents.

When we associated the pre-moistening time with the tetrazolium solution concentration, we observed that the most suitable for $J$. mollissima seeds was 16 hours of premoistening and concentration of $0.25 \%$ of the tetrazolium solution. This treatment allowed a uniform coloration of the seeds, allowing better visual interpretation of the characteristics. According to Mercado and Delgado (2018) from the reduction of tetrazolium salt in triphenyl formazan, it is possible to identify the seed viability because tissues with more respiratory activity showed a more intense red color and tissues with lower respiratory intensity showed pink or white color.

The results observed in the tetrazolium analysis were compatible with the germination test, where there was a mean percentage of $22.5 \%$ of seeds germinated for the treatment between paper and $13.5 \%$ for treatment with vermiculite, denoting the effectiveness of the protocol (table 2).

Table 1. Viability of Jatropha mollissima seeds submitted to two concentrations (\%) and time (h) of exposure in tetrazolium.

Viabilidad de las semillas de Jatropha mollissima sometida a dos concentraciones de tetrazólio y tiempo de exposición.

\begin{tabular}{ccccccc}
\hline & \multicolumn{2}{c}{$12 \mathrm{~h}$} & \multicolumn{2}{c}{$14 \mathrm{~h}$} & \multicolumn{2}{c}{$16 \mathrm{~h}$} \\
\cline { 2 - 7 } Type of seeds & 0.25 & 0.50 & 0.25 & 0.50 & 0.25 & 0.50 \\
& $\%$ & $\%$ & $\%$ & $\%$ & $\%$ & $\%$ \\
\hline Viable (\%) & 21 & 29 & 20 & 25 & 25 & 28 \\
Unviable (\%) & 64 & 66 & 73 & 68 & 68 & 60 \\
Deteriorated (\%) & 15 & 5 & 7 & 7 & 7 & 12 \\
\hline
\end{tabular}

Table 2. Percentage of germination $(\% \mathrm{G})$, germination speed index (GSI) and mean germination time (MGT) of Jatropha mollissima seeds.

Valores encontrados para porcentaje $(\% \mathrm{G})$, índice de velocidad (IVG) y tiempo de germinación medio (TGM) de semillas de Jatropha mollissima.

\begin{tabular}{cccc}
\hline Treatments & $\% \mathrm{G}$ & GVI & MGT \\
\hline Between paper (BP) & $22.5 \mathrm{a}$ & $1.60 \mathrm{a}$ & $7.20 \mathrm{a}$ \\
Vermiculite (FV) & $13.5 \mathrm{a}$ & $0.92 \mathrm{a}$ & $7.36 \mathrm{a}$ \\
\hline
\end{tabular}

Equal letters do not differ from each other by the Tukey test at $5 \%$ probability.
Seed germination in the BP treatment was more homogeneous concerning seed germination in FV treatment. The results obtained for the germination between paper resemble the values found in the viability of the seeds by the tetrazolium test in which, for the treatment with a better combination of pre-moistening (16 hours) and tetrazolium concentration $(0.25 \%)$, the percentage of viable seeds was equal to $23 \%$.

\section{DISCUSSION}

The treatments submitted to $0.5 \%$ concentration of tetrazolium solution, even with a higher percentage of viable seeds, did not show uniformity in staining. This disuniformity influences the results due to the concentration of the solution and the time of exposure, making it difficult to interpret and differentiate the living (viable), deteriorated or dead tissues (unviable) (Añez et al. 2005, Lima et al. 2010, Mercado et al. 2018). One of the limitations of this test, described by França-Neto and Krzyzanowsk (2019), is that it requires training and knowledge of seed structures and proper tetrazolium interpretation. It is even more difficult concerning forest seedlings, which are not frequently studied and differentiate a lot among species.

Evaluating the seeds of Jatropha elliptica Müll. Arg., Añez et al. (2005) defined that with the concentration of a $1 \%$ solution, it is possible to obtain good results with only 60 minutes of staining. When the concentration of the solution is reduced to $0.1 \%$, the same authors indicate that the seeds stay at least 180 minutes in the solution, at temperatures of 30,35 and $40{ }^{\circ} \mathrm{C}$. For seeds of Sebastiania commersoniana (Baill.) Smith et Downs, Santos et al. (2006) recommend that, for the evaluation of tetrazolium, the seeds be maintained at $30^{\circ} \mathrm{C}$ with the concentration of $0.1 \%$ solution for 2 hours or $0.05 \%$ for 4 hours. Pinto et al. (2009) defined that the best method of imbibition for seeds of Jatropha curcas is between paper until reaching $30 \%$ of moisture content and concentration of $0.5 \%$ of tetrazolium solution.

The fact that it excludes environmental disturbances that could affect other evaluation tests and the possibility to diagnose seed deterioration and even its causes makes this test the best option for evaluating the physiological quality of seeds (França-Neto and Krzyzanowski 2019). Another positive point regarding the results obtained in the tetrazolium and germination tests refers to the speed for the assessments (Corte et al. 2010, Lima et al. 2010). With the tetrazolium test for J. mollissima, it is possible to obtain results with only 24 hours and using the germination test, this time increases to a minimum of 10 days for obtaining consistent results.

\section{CONCLUSIONS}

It is suggested that the best procedure for performing the Tetrazolium test on Jatropha mollissima seeds is the 
pre-moistening of 16 hours at $25{ }^{\circ} \mathrm{C}$ and staining for 4 hours at $40{ }^{\circ} \mathrm{C}$ in the dark and tetrazolium solution with a concentration of $0.25 \%$.

\section{ACKNOWLEDGMENTS}

This study was carried out with the support of the Coordenação de Aperfeiçoamento de Pessoal de Nível Superior - Brasil (CAPES) - Financing code 001. The authors also thank the Nucleus of Ecology and Environmental Monitoring (NEMA/UNIVASF) and the São Francisco Integration Project (PISF) for collecting and processing the seeds used in this work.

\section{REFERENCES}

Añez LMM, MFB Coelho, MCF Albuquerque, EAF Mendonça, JLD Dombroski. 2005. Padronização da metodologia do teste de tetrazólio para sementes de Jatropha elliptica M. Arg. (Euphorbiaceae). Revista Brasileira de Plantas Medicinais 9(3): 82-88.

Barros ASR, J. Marcos Filho. 1990. Testes para avaliação rápida da viabilidade de sementes de soja. Pesquisa Agropecuária Brasileira 24(10): 1447-1459.

Corte VB, EEL Borges, BLC Pereira. 2010. Adequação da metodologia do teste de tretazólio para avaliação da viabilidade de sementes de Melanoxylon braúna Schot. Cerne 16(3): 415-421. DOI: http://dx.doi.org/10.1590/S0104$\underline{77602010000300018}$

Dantas BF, JR Matias, RC Ribeiro. 2015. Teste de tetrazólio para avaliar viabilidade e vigor de sementes de espécies florestais da Caatinga. Informativo ABRATES 25(1): 60-64.

Deminicis BB, PR Rodrigues, BP Faria, HD Vieira, AD Pandolfi Filho, G.S Freitas. 2014. Tetrazolium test to evaluate Stizolobium aterrimum seeds quality. American Journal of Plant Sciences 5: 148-152. DOI: http://dx.doi.org/10.4236/ ajps.2014.51019

Ferreira AG, F Borghetti (eds). 2004. Germinação: do básico ao aplicado. Porto Alegre, Brasil. Artmed. 323 p.

França Neto JB, FC Krzyzanowski, NP Costa. 1998. O teste de tetrazólio em sementes de soja. Londrina, Brasil. EMBRAPA-CNPSo. 72 p. (EMBRAPA-CNPSo. Documentos, 116)

França Neto JB, FC Krzyzanowski. 2019. Tetrazolium: an important test for physiological seed quality evaluation. Journal of Seed Science 41(3):359-366. DOI: https://doi. org/10.1590/2317-1545v41n3223104

Gomes JAS. 2015. Inibição dos efeitos locais induzidos pelas peçonhas das serpentes Bothrops erythomelas e Bothrops jararaca pelo extrato aquoso das folhas de Jatropha mollissima Pohl Bail. Dissertação (Mestrado) Programa de Pós-Graduação em Ciências Farmacêuticas. Natal, Brasil. Universidade Federal do Rio Grande do Norte. 64 p.

IBGE (Instituto Brasileiro de Geografia e Estatística, BR). 2012. Manuais Técnicos de Geociências, $n^{\circ}$ 1: Manual Técnico da Vegetação Brasileira. 2 ed. Rio de Janeiro, Brasil. IBGE. 275 p.

Labouriau LG. 1983. A germinação das sementes. Washington, USA. OEA. 174 p.

Lima LB, TLF Pinto, ADLC Novembre. 2010. Avaliação da Viabilidade e do Vigor de Sementes de Pepino pelo Teste de Tetrazólio. Revista Brasileira de Sementes 32(1):060-068.
DOI: https://doi.org/10.1590/S0101-31222010000100007

Lima BG. 2012. Caatinga: espécies lenhosas e herbáceas. Mossoró, Brasil. Ufersa. 316 p.

Loureiro MB, CAS Teles, CCA Colares, BRN Araújo, LG Fernandez, RD Castro. 2013. Caracterização morfoanatômica e fisiológica de sementes e plântulas de Jatropha curcas L. (Euphorbiaceae). Revista Árvore 37(6):1093-1101. DOI: http://dx.doi.org/10.1590/S0100-67622013000600011

Maia GN. 2012. Caatinga: árvores e arbustos e suas utilidades. 2nd. ed. Fortaleza, Brasil. Printcolor Gráfica e Editora. 413 p.

Maguire JD. 1962. Speed of germination-ais in selection and evaluation for seedlings emergence and vigour. Crop Science Madson 2(2): 176-177. DOI: http://dx.doi.org/10.2135/ cropsci1962.0011183X000200020033x

MAPA (Ministério da Agricultura, Pecuária e Abastecimento, BR). 2009. Regra para análises de sementes. Brasília, Brasil. MAPA/ACS. 395 p.

Marcos Filho J. 2015. Fisiologia de sementes de plantas cultivadas. Londrina, Brasil. Abrates. 659 p.

Mercado SAS, EDB Delgado. 2018. Viabilidad de semillas de Glycine max (L.) utilizando la prueba de tetrazólio. Revista de Investigación Agraria y Ambiental 9(2): 89-98. DOI: $\underline{10.22490 / 21456453.2270}$

Mercado SAS, HAM Bayona, JDQ Caleño. 2018. Evaluación de la calidad fisiológica de las semillas de Linum usitatissimum L. con la prueba de tetrazólio. Avances en Investigación Agropecuaria 22(3). DOI: http://www.redalyc.org/ articulo.oa? id $=83758178005$

Neves EL, LS Funch, BF Viana. 2010. Comportamento fenológico de três espécies de Jatropha (Euphorbiaceae) da Caatinga, semi-árido do Brasil. Revista Brasileira de Botânica 33(1): 155-166. DOI: http://dx.doi.org/10.1590/S0100$\underline{84042010000100014}$

Neves EL, IC Machado, BF Viana. 2011. Sistemas de polinização e de reprodução de três espécies de Jatropha (Euphorbiaceae) na Caatinga, semi-árido do Brasil. Revista Brasileira de Botânica 34(4): 553-563. DOI: http://dx.doi. org/10.1590/S0100-84042011000400009

Oliveira LM, CM Caldeira, LAS Abreu, MLM Carvalho, CD Silva. 2014. An alternative procedure for evaluating the quality of castor seeds by the tetrazolium test. African Journal of Agricultural Research 9(35): 2664-2668. DOI: https://doi. org/10.5897/AJAR2014.8962

Paterlini P, GS Jaime, CAC Olivaro, MI Gómez, K Cruz, U Tonello, CM Romero. 2019. Seeds characterization of wild species Jatropha peiranoi endemic of arid areas of Monte Desert Biome, Argentina. Industrial Crops \& Products 141(111796). DOI: https://doi.org/10.1016/j.indcrop. 2019.111796

Pinto TLF, J. Marcos Filho, VA Forti, C Carvalho, FG Gomes Junior. 2009. Avaliação da viabilidade de sementes de pinhão manso pelos testes de tetrazólio e de raio X. Revista Brasileira de Sementes 31(2): 195-201. DOI: http://dx.doi. org/10.1590/S0101-31222009000200023

Queiroz MF, PD Fernandes, J Dantas Neto, NHC Arriel, FJL Marinho, SF Leite. 2013. Crescimento e fenologia de espécies de Jatropha durante a estação chuvosa. Revista Brasileira de Engenharia Agrícola e Ambiental 17(4): 405-411. DOI: http://dx.doi.org/10.1590/S1415-43662013000400008

Santos SRG, RC Paula, CA Fogaça, FV Môro, RS Costa. 2006. Viabilidade de sementes de Sebastiania commersoniana 
(Baill.) Smith \& Downs (branquilho) - Euphorbiaceae pelo teste de tetrazólio. Cientifica 34(1): 39-45.

Souza DD, NB Cavalcante. 2019 Biometria de frutos e sementes de Jatropha mollissima (Pohl) Baill. (Euphorbiaceae). Acta Biológica Catarinense 6(2): 115-122. DOI: http://dx.doi. org/10.21726/abc.v6i2.663

Vasconcelos GCL, FS Fernandes, AM Amador, KAM Amador, NHC Arriel. 2014. Caracterização morfológica de Jatropha mollissima (Pohl) Baill. Revista Verde 9(3): 263-268. http:// oaji.net/articles/2015/2238-1445802863.pdf

Recibido: 09/12/19

Aceptado: 12/03/20 